\title{
Prolapsing mass in the caecum: learning point for the colonoscopist
}

\author{
Osian James, Gethin Llewellyn Williams
}

Colorectal Surgery, Royal Gwent Hospital, Newport, UK

\section{Correspondence to}

Osian James,

osianpjames@gmail.com

Accepted 3 April 2019

\section{DESCRIPTION}

A 47-year-old woman attended her first screening colonoscopy due to a strong family history of colorectal cancer. She is asymptomatic. Her only medical history is of well-controlled endometriosis for which she had a laparoscopic ablation with incidental appendicectomy 7 years ago.

Within the caecum, an apparent large submucosal polyp was observed (figure 1). This atypical solid mass displayed normal mucosal pit patterns and appeared to exert external compression rather than being a true intraluminal mass typical of malignancy. Multiple biopsies were sent for histology. The remainder of the examination was normal (anus to terminal ileum). Subsequently, CT

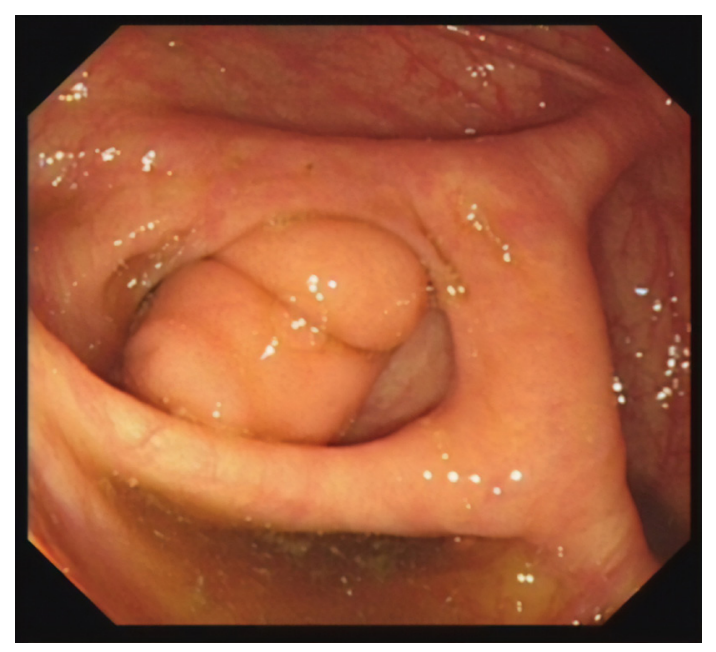

Figure 1 Colonoscopic image of the mass at the appendiceal orifice.

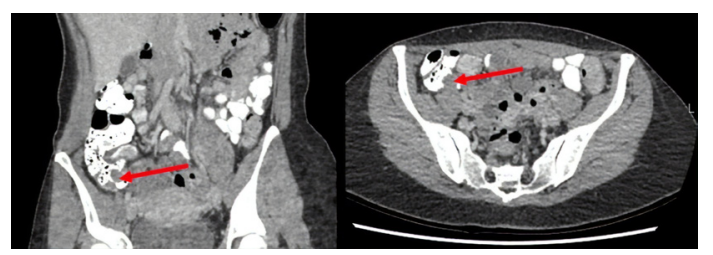

Figure 2 CT image of the mass. Red arrow highlights the mass in question. revealed a submucosal polypoid mass at the caecum without abnormal abdominopelvic lymphadenopathy or metastatic disease (figure 2). Subsequently, histology results were returned showing normal colonic mucosa.

Detailed discussions were held with the patient, reaching an informed decision to proceed with surgery largely due to the diagnostic uncertainty and her strong family history of colorectal cancer. Critically, the role of the surgeon here was as an adviser, with the patient ultimately the decision-maker.

A diagnostic laparoscopy was performed, confirming an absent appendix, but a $25 \mathrm{~mm}$ palpable mass at the caecal pole corresponding to the lesion previously identified. The surgeon proceeded to perform an uncomplicated laparoscopic caecectomy. Final histology of the mass included a $5 \mathrm{~mm}$ appendix stump and endometrial glands and stroma with muscular hyperplasia consistent with endometriosis.

\section{Learning points}

- Endometriosis of the appendix is a rare but recognised condition which may cause a variety of non-specific symptoms. ${ }^{1}$

- This report suggests it must always be considered in pre-menopausal women with positive colonoscopic findings, even with a history of previous appendicectomy.

- We reiterate that doctors must empower patients to become informed decision-makers.

Contributors $0 \mathrm{~J}$ has produced this original work, under the supervision and guidance of GLW.

Funding The authors have not declared a specific grant for this research from any funding agency in the public, commercial or not-for-profit sectors.

Competing interests None declared.

Patient consent for publication Obtained.

Provenance and peer review Not commissioned; externally peer reviewed.

\section{REFERENCE}

1 Collins DC. A study of 50,000 specimens of the human vermiform appendix. Surg Gynecol Obstet 1955;101:437-45. 
Images in...

Copyright 2019 BMJ Publishing Group. All rights reserved. For permission to reuse any of this content visit https://www.bmj.com/company/products-services/rights-and-licensing/permissions/

BMJ Case Report Fellows may re-use this article for personal use and teaching without any further permission.

Become a Fellow of BMJ Case Reports today and you can:

- Submit as many cases as you like

- Enjoy fast sympathetic peer review and rapid publication of accepted articles

Access all the published articles

- Re-use any of the published material for personal use and teaching without further permission

For information on Institutional Fellowships contact consortiasales@bmjgroup.com

Visit casereports.bmj.com for more articles like this and to become a Fellow 